\title{
С.В. ЯГЕЛЮК
}

Луиьький національний технічний університет

О.О. ЯГЕЛЮК

Луиький наиіональний технічний університет

\section{СПОЖИВНІ ВЛАСТИВОСТІ ДРУКОВАНОЇ ПРОДУКЦЇ, ПРИЗНАЧЕНОЇ ДЛЯ ДЕРЖАВНИХ ЛІСОВИХ ГОСПОДАРСТВ}

С.В. ЯГЕЛЮК

Луизкий национальний технический университет

А.А. ЯГЕЛЮК

Луиякий национальний технический университет

\section{ПОТРЕБИТЕЛЬСКИЕ СВОЙСТВА ПЕЧАТНОЙ ПРОДУКЦИИ, ПРЕДНАЗНАЧЕННОЙ ДЛЯ ГОСУДАРСТВЕННЫХ ЛЕСНЫХ ХОЗЯЙСТВ}

\author{
S.V. YAGELYUK \\ Lutsk National Technical University \\ A.A. YAGELYUK \\ Lutsk National Technical University
}

\section{CONSUMER PROPERTIES OF PRINTED PRODUCTION, INTENDED FOR STATE FORESTRY FARMS}

\section{https://doi.org/10.36910/6775-2310-5283-2018-11-20}

Мета. Визначення основних споживчих властивостей нової лінійки стендів, розроблених та виготовлених для державних лісових господарств і призначених для дітей.

Методика. Під час проведення дослідження використовувались загальнонаукові аналітичні методи, а також методи аналогії та прототипів для отримання практичних результатів.

Результати. У статті розглянуті особливості стендів для державних лісових господарств, як один з видів поліграфічної продукиії. Встановлені основні споживчі властивості стендів для державних лісових господарств та фактори, щуо впливають на їх формування. Подано характеристику нової розробленої лінійки стендів «Майбутнє лісу в руках дітей», призначеної для дошкільнят та дітей молодшого шкільного віку. Лінійка стендів «Майбутнє лісу в руках дітей» відповідає функціональному призначенню, виконує агітаційну функиію - надає інформаиію про загальні правила поведінки дітей та дорослих у лісі. Також важливими функціями стендів є навчальна і виховна, щзо забезпечує виховання загальнолюдських иінностей. Лінійка стендів «Майбутнє лісу в руках дітей» є своєрідною візитною карткою державного підприємства «Попільнянський лісгосп».

Наукова новизна. Дизайн-розробка лінійки стендів «Майбутнє лісу в руках дітей» $\epsilon$ вперше представленою авторською роботою та охоплює лінійку розроблених, виготовлених та застосованих стендів для лісових господарств. Новизна також полягає у виявленні формоутворюючих особливостей і соціально-культурної ролі стендів для лісових господарств як об’єкта графічного дизайну в прочесі естетично- функиіонального формування сучасного середовища. 
Практичне значення. Розроблені, виготовлені $і$ встановлені стенди для лісового господарства. Замовником виступає державне підприємство «Попільнянський лісгосп». Розробка є власністю фірми «Золота стріла».

Ключові слова: споживчі властивості, стенд, лісове господарство, діти.

\section{Постановка проблеми у загальному вигляді та їі зв'язок 3} важливими науковими $\mathbf{i}$ практичними завданнями. Державні лісогосподарські підприємства та національні парки здійснюють інформаційну, навчальну, агітаційну діяльність 3 допомогою сучасної поліграфічної продукції. Керівники лісових господарств створюють робочі групи із розробки проектів агітаційного наповнення із залученням фахівців різних напрямків: дизайнерів, біологів, лісників, товарознавців і т.д. Найкращим засобом подання інформації залишається стенд. Стенд вже давно зарекомендував себе в якості одного з найефективніших засобів розміщення інформаційних матеріалів, презентацій, реклами в межах безпосередньої досяжності людей. Особлива увага звертається саме на наповнення стенду. На сьогодні розроблена велика кількість стендів різних напрямків та інформаційного наповнення для дорослого населення. Однак на екскурсію чи відпочинок в ліс зазвичай відправляються родинами і вже з наймолодшого віку необхідно привчати майбутніх громадян бережному ставленню до лісу та його багатств. Тому дослідження споживних властивостей лінійки спеціальних стендів для дітей молодшої вікової групи для використання державними лісгоспами та національними парками є актуальним завданням, що має практичне значення.

Аналіз останніх досліджень, у яких започатковано вирішення проблеми. На сьогодні $\epsilon$ багато досліджень споживних властивостей поліграфічної продукції та інших непродовольчих товарів. Вітчизняні та зарубіжні вчені вивчали ці питання $[1,4,7]$. Проте недосліджені споживні властивості інформаційних стендів [2,3], призначених для державних лісових господарств. Цим питанням присвячена дана стаття.

Цілі статті. Визначення основних споживних властивостей нової лінійки стендів, розроблених та виготовлених для державних лісових господарств і призначених для дітей.

Виклад основного матеріалу дослідження 3 повним обгрунтуванням отриманих наукових результатів. Стенд - інформаційний та рекламний інструмент. Сфера використання стендів безмежна. Окрема галузь застосування стендів, яка має свої особливості - державні лісові господарства. Стенди для лісових господарств за змістом і виконанням можна розділити на 
кілька видів: інформаційні, навчальні, презентаційні, рекламні та інші. За наповненням стенди можуть бути 3 незмінною інформацією і стенди 3 періодично змінною інформацією $[1,2,8]$. За способом розміщення інформації - стенди 3 пласкими кишенями i об'ємними кишенями, нестандартні. За сферою застосування - вуличні та офісні. Стенди для державних лісових господарств розміщені на вулиці та піддаються активному впливу навколишнього середовища. Такі стенди виготовляються зі спеціальних матеріалів, стійких до дії зовнішнього середовища. До інформаційного стенду ставляться такі вимоги: тематична цілеспрямованість матеріалів і виділення провідної теми; виразність композиції матеріалу; гармонійність колірного рішення; можливість швидкої заміни застарілої інформації, лаконічність наповнення інформацією

Як критерій успішного вирішення композиції можна назвати наступні фактори: колір шрифту і колір фону забезпечують чітке і зручне сприйняття тексту; загальне кольорове рішення сприяє емоційному вираженню i розкриття теми експозиції; колірне рішення гармонійно пов'язане 3 експозицією.

В основу розробки лінійки стендів «Майбутнє лісу в руках дітей» покладена ідея виховання поважного ставлення до лісу з допомогою героїв відомих казок і мультиплікаційних персонажів. Поєднання казкових елементів вчить дітей добре бачити і розуміти все навколо, глибоко проникати в складні взаємини поміж людьми та природою, розпізнавати хто друг, а хто ворог у лісі, не бути байдужим до тварин та рослин. Вже змалку дітей треба привчати, що ліс це багатство країни і потребує поважного ставлення, а також роз'яснювати, як себе поводити у надзвичайних випадках. Щоб діти могли зрозуміти та усвідомити інформацію, стенди повинні бути 3 наочним зображенням та моделюванням ситуації. Також вони повинні бути яскравими, барвистими, але лаконічними [3, 5, 8].

На кожному стенді лінійки "Майбутнє лісу в руках дітей" присутнє просте та влучне, легке для сприйняття гасло, сюжет, що його підтверджує і $є$ основною графічною складовою стенду та фонове зображення у вигляді природного пейзажу. Лінійка виконана у двох різних варіантах iз використанням двовимірних і тривимірних зображень. Сюжет передається за допомогою мультиплікаційних персонажів, що зображуються у певних ситуаціях, і зрозуміло дають дітям зрозуміти що таке ліс, та демонструють їм базові правила поведінки у ньому (рис. 1). 


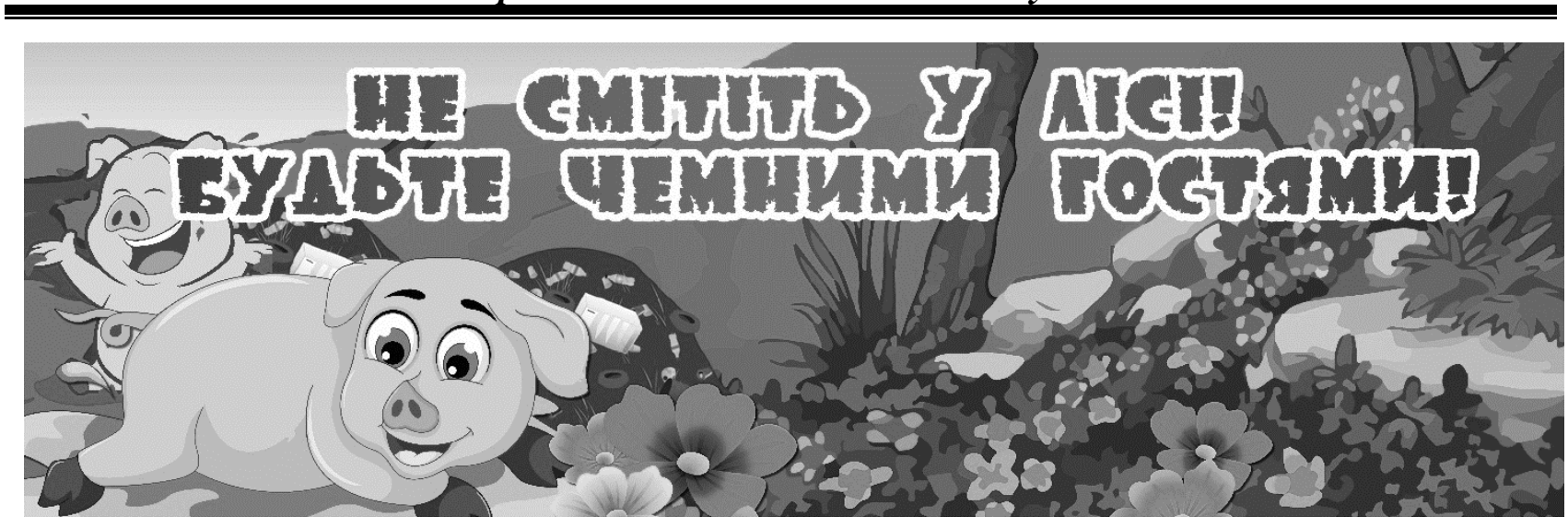

\section{Рис. 1. Приклад стенда з лінійки «Майбутнє лісу в руках у дітей»}

Основні споживні властивості визначаються метою споживання та споживчими потребами [6, 7]. Дизайн лінійки стендів «Майбутнє лісу в руках у дітей» відповідає сучасним вимогам державних лісогосподарств, а саме: багатоцільове призначення, високохудожній рівень оформлення стендів для дітей за допомогою використання найновітніших технологічних можливостей.

Лінійка стендів «Майбутнє лісу в руках дітей» відповідає функціональному призначенню, виконує агітаційну функцію - надає інформацію про загальні правила поведінки дітей та дорослих у лісі. Також важливими функціями стендів $\epsilon$ навчальна i виховна, що забезпечує виховання загальнолюдських цінностей. Блискуча поверхня забезпечує приємні відчуття.

Щоб відповідати своєму призначенню, стенди з лінійки «Майбутнє лісу в руках дітей» повинні бути оптимально розташовані. При їх конструюванні та раціональному розташуванні необхідно зважати на такі ергономічні вимоги:

- антропометричні, тобто відповідність розмірів обладнання i функціонального простору розмірам тіла дитини в статиці та динаміці; Розміри персонажів на стенді наближуються чи співпадають 3 розмірами дитини. Це створює «ефект присутності» для дитини;

- біомеханічні, що передбачають дотримання біомеханічних умов рівноваги тіла дитини. Стенд розташований на висоті 80 - 100 см від поверхні землі щоб забезпечити вільний доступ до персонажів;

- фізіологічні, які передбачають забезпечення насамперед нормального зорового сприймання, вільного дихання, правильного кровообігу, оптимальних затрат енергії; колір вибирається для полегшення сприйняття дитиною, образів - пожежа червона, яскраві сигнальні кольори, зелений заспокійливий і т.д.; 
- соціально-психологічні. Лінійка стендів задовольняє в повній мірі, оскільки виконує свою важливу презентаційну функцію. Відсутність агресії у зображеннях, не травмує психіку дитини.

Як критерій успішного вирішення композиції можна назвати такі естетичні властивості розробленої лінійки стендів: колір шрифту і колір фону забезпечують чітке і зручне сприйняття тексту; загальне кольорове рішення сприяє емоційному вираженню і розкриття теми експозиції; колірне рішення гармонійно пов'язане 3 експозицією. Гармонізації середовища служить балансування кольору: яскраві кольори врівноважуються приглушеними, холодні-теплими, темні-світлими. Композиційне рішення стенду симетричне або асиметричне.

За графічними, композиційними та функціональними ознаками досліджувані стенди виконані на високому професійному рівні. Про це, зокрема, свідчить їх виразна та гармонійна форма. У ній спостерігається цілеспрямований пошук форми, що забезпечується дотриманням основних законів і засобів композиції. Завдяки лаконічності та виразності форми стенди можуть використовуватися як аналоги для подальшого проектування.

Висновки. В статті проаналізовані лінійки стендів розроблені та виготовлені дизайнерською фірмою «Золота стріла». Всі наведені аналоги відносяться до вуличних стендів і розташовуються на території державних лісових господарств у зручних для читання місцях або місцях відпочинку.

В основу розробки лінійки стендів «Майбутнє лісу в руках дітей» покладена ідея виховання поважного ставлення до лісу з допомогою героїв відомих казок і мультиплікаційних персонажів. Лінійка стендів «Майбутнє лісу в руках дітей» відповідає функціональному призначенню, виконує агітаційну функцію - надає інформацію про загальні правила поведінки дітей та дорослих у лісі. Також важливими функціями стендів $\epsilon$ навчальна i виховна, що забезпечує виховання загальнолюдських цінностей. Лінійка стендів «Майбутнє лісу в руках дітей» $\epsilon$ своєрідною візитною карткою державного підприємства «Попільнянський лісгосп», а отже, лінійка виконує і ідентифікаційну, і рекламну функції, так як у інших лісогосподарських підприємств подібних стендів немає. Спроектована лінійка стендів відповідає ергономічним вимогам так як розміщена на рівні зросту дитини, Розміри персонажів на стенді наближуються чи співпадають з розмірами дитини. Це створює «ефект присутності». Кольорова гама вибирається для полегшення сприйняття дитиною, образів - пожежа червона, яскраві сигнальні кольори, зелений колір - заспокійливий і т.д. Стенди виконані з матеріалів, які не 
піддаються впливу навколишнього середовища і контакт 3 ними не шкодить здоров’ю дитини. Відсутність агресії у зображеннях, не травмує психіку дитини. Розробка є власністю фірми «Золота стріла».

\section{Література}

1. Дижур А.Л. Начало Баухауза // Техн. Эстетика. - 1989. - № 12. - С. 24-26

2. Тисяча пропозицій від лідера. Золота стріла. [Електронний ресурс]. - Режим доступу: https://www.lisportal.org.ua/28164/

3. Золота стріла. Каталог продукції. [Електронний ресурс]. - Режим доступу: https://www.scribd.com/doc/201230509/Каталог-продукції-2014

4. Станкевич Н. Рекламний плакат з найдавніших часів до поч. ХХ століття / Н. Станкевич // Мистецтвознавство'09: Науковий збірник. - Львів: СКІМ, 2009. - С.111-118.

5. Богуш А., Гавриш Н., Котик Т. Методика організації художньо-мовленевої діяльності дітей у дошкільних навчальних закладах. - Київ: Видавничий дім Слово, 2006. $175 \mathrm{c}$.

6. Ягелюк С.В., Ягелюк О.О. Формування естетичних властивостей сучасних меблів. Товарознавчий вісник. Збірник наукових праць. Випуск 8. - Луцьк. ЛНТУ, 2015. стор. $130-135$

7. Товарознавство непродовольчих товарів: підруч. для студ. вищіх навч. закл.: в 2-х частинах./ [Л.І. Байдакова, O.I. Передрій, С.В. Ягелюк та ін.] - Луцьк : РВВ Луцького НТУ, 2014. $-625 \mathrm{c}$.

8. Стефанов С. И. Реклама и полиграфия: опыт словаря - справочника. - М.: Гелла принт, 2004. - 320 с: ил. - (Рекламные технологии).

Цель. Определение основных потребительских свойств новой линейки стендов, разработанных и изготовленных для государственных лесных хозяйств и предназначенных для детей.

Методика. При проведении исследования использовались общенаучные аналитические методы, а также методы аналогии и прототипов для получения практических результатов.

Результаты. В статье рассмотрены особенности стендов для государственных лесных хозяйств, как вида полиграфической продукиии. Определены основные потребительские свойства стендов для государственных лесных хозяйств и факторы, влияюшие на их формирование. Дана характеристика новой разработанной линейки стендов «Будущее леса в руках детей», предназначенной для дошкольников и детей младшего школьного возраста. Линейка стендов «Будущее леса в руках детей» соответствует функииональному назначению, выполняет агитационную функиию предоставляет информаџию об общих правилах поведения детей и взросльх в лесу. Также важными функииями стендов является учебная и воспитательная. Они обеспечивают формирование у детей общечеловеческих иенностей. Линейка стендов «Будущее леса в руках детей» является своеобразной визитной карточкой государственного предприятия «Попельнянский лесхоз».

Научная новизна. Дизайн-разработка линейки стендов «Будущее леса в руках детей» является впервые представленной авторской работой и охватывает линейку разработанных, изготовленных стендов для лесных хозяйств. Новизна также заключается в выявлении формообразующих особенностей и соџиально-культурной роли стендов для лесных хозяйств как объекта графического дизайна в процессе естетически- 
функционального формирования современного пространства.

Практическое значение. Разработанные стенды изготовлены и установленыл. Заказчиком выступает государственное предприятие «Попельнянский лесхоз». Разработка является собственностью фирмы «Золотая стрела».

Ключевые слова: потребительские свойства, стенд, лесное хозяйство, дети

Goal. Identification of the main consumer properties of a new range of stands designed and manufactured for state forestry and intended for children.

Methodology. The research used general scientific analytical methods, as well as analogy and prototype methods to obtain practical results.

Results. In the article features of stands for state forestry enterprises are considered, as a kind of polygraphic production. The main consumer properties of stands for state forestry enterprises and the factors that shape them are determined. The characteristic of the new developed line of stands "Future of the forest in the hands of children" is given. It is intended for preschoolers and children of primary school age. The range of stands "The future of the forest in the hands of children" corresponds to its functional purpose, fulfills its agitational function. Provides information on general rules of behavior for children and adults in the forest. Also, the important functions of the stands are educational. They ensure the formation of universal human values among children. The range of stands "The future of the forest in the hands of children" is a kind of visiting card of the state enterprise "Popelnyansky Leskhoz".

Scientific novelty. The design of the stand series "Future of the forest in the hands of children" is the first time presented by the author's work and covers a line of developed, manufactured stands for forestry.

Practical significance. The developed stands are manufactured and installed. The customer is the state enterprise "Popelnyansky Leskhoz". Development is the property of the firm «Zolota strila».

Keywords: consumer properties, stand, forestry, children.

Рекомендовано до публікачії докт.техн.наук, професором Луиького НТУ Байдаковою Л.І. Дата надходження в редакиію 22.02.2018 p. 